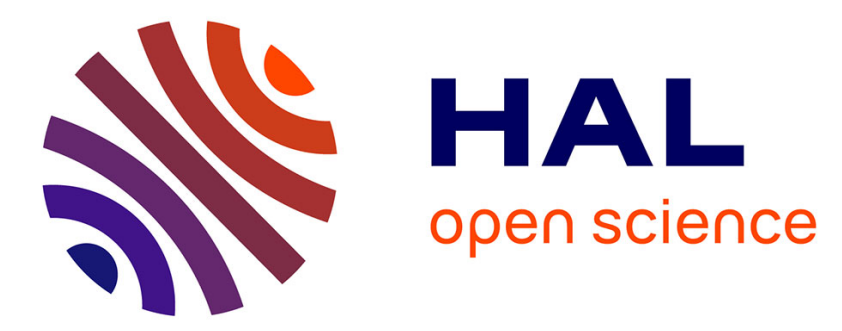

\title{
Frequency, clinical characteristics and genotype distribution of rotavirus gastroenteritis in Greece (2007-2008)
}

Dimitra Koukou, Ioanna Grivea, Eleftheria Roma, Heleni Tsioni, Georgios Trimis, Emmanuel Galanakis, Evagelia Farmaki, Elias Iosifidis, A Michos, Antigoni Siamopoulou-Mavridou, et al.

\section{To cite this version:}

Dimitra Koukou, Ioanna Grivea, Eleftheria Roma, Heleni Tsioni, Georgios Trimis, et al.. Frequency, clinical characteristics and genotype distribution of rotavirus gastroenteritis in Greece (2007-2008). Journal of Medical Virology, 2010, 83 (1), pp.165. 10.1002/jmv.21945 . hal-00599790

\section{HAL Id: hal-00599790 \\ https://hal.science/hal-00599790}

Submitted on 11 Jun 2011

HAL is a multi-disciplinary open access archive for the deposit and dissemination of scientific research documents, whether they are published or not. The documents may come from teaching and research institutions in France or abroad, or from public or private research centers.
L'archive ouverte pluridisciplinaire HAL, est destinée au dépôt et à la diffusion de documents scientifiques de niveau recherche, publiés ou non, émanant des établissements d'enseignement et de recherche français ou étrangers, des laboratoires publics ou privés. 


\section{Journal of Medical Virology}

WILEY

\section{Frequency, clinical characteristics and genotype distribution of rotavirus gastroenteritis in Greece (2007-2008)}

\begin{tabular}{|c|c|}
\hline Journal: & Journal of Medical Virology \\
\hline Manuscript ID: & JMV-10-1874.R1 \\
\hline Wiley - Manuscript type: & Research Article \\
\hline $\begin{array}{r}\text { Date Submitted by the } \\
\text { Author: }\end{array}$ & 07-Aug-2010 \\
\hline Complete List of Authors: & $\begin{array}{l}\text { Koukou, Dimitra; Aghia Sophia Children's Hospital, First } \\
\text { Department of Pediatrics, Athens University } \\
\text { Grivea, Ioanna; University Hospital of Larissa, Pediatric Department } \\
\text { Roma, Eleftheria; Aghia Sophia Children's Hospital, First } \\
\text { Department of Pediatrics, Athens University } \\
\text { Tsioni, Heleni; University Hospital of Ioannina, Department of } \\
\text { Pediatrics } \\
\text { Trimis, Georgios; Aghia Sophia Children's Hospital, First } \\
\text { Department of Pediatrics, Athens University } \\
\text { Galanakis, Emmanuel; University Hospital of Heraklion, Department } \\
\text { of Pediatrics } \\
\text { Farmaki, Evagelia; Ippokration Hospital of Thessaloniki, First } \\
\text { Department of Pediatrics, Aristotle University } \\
\text { Iosifidis, Elias; Ippokration Hospital of Thessaloniki, } \\
\text { Third Department of Pediatrics, Aristotle University } \\
\text { Michos, A; Aghia Sophia Children's Hospital, First Department of } \\
\text { Pediatrics, Athens University } \\
\text { Siamopoulou-Mavridou, Antigoni; University Hospital of Ioannina, } \\
\text { Department of Pediatrics } \\
\text { Kalmanti, Maria; University Hospital of Heraklion, Department of } \\
\text { Pediatrics } \\
\text { Papadopoulou, Heleni; Ippokration Hospital of Thessaloniki, First } \\
\text { Department of Pediatrics, Aristotle University } \\
\text { Roilides, Emmanuel; Ippokration Hospital of Thessaloniki, } \\
\text { Third Department of Pediatrics, Aristotle University } \\
\text { Theodoridou, Maria; Aghia Sophia Children's Hospital, First } \\
\text { Department of Pediatrics, Athens University } \\
\text { Syrogiannopoulos, George; University Hospital of Larissa, Pediatric } \\
\text { Department } \\
\text { Syriopoulou, Vassiliki; Aghia Sophia Children's Hospital, First } \\
\text { Department of Pediatrics, Athens University }\end{array}$ \\
\hline
\end{tabular}




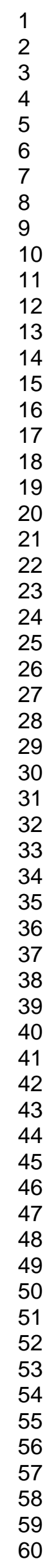

\section{SCHOLARONE ${ }^{m}$ \\ Manuscripts}

10

12

13

14

15

16

18

19

20

22

23

25

26

27

29

32

33

34

36

37

38

40

41

42

44

45

46

47

48

50

51

52

53

54

56

57

58

60

John Wiley \& Sons 


\section{"Frequency, clinical characteristics and genotype distribution of rotavirus gastroenteritis in Greece (2007-2008)"}

Dimitra Koukou, ${ }^{1}$ Ioanna Grivea, ${ }^{2}$ Eleftheria Roma, ${ }^{1}$ Heleni Tsioni, ${ }^{3}$ Georgios Trimis, ${ }^{1}$ Emmanuel Galanakis, ${ }^{4}$ Evagelia Farmaki, ${ }^{5}$ Elias Iosifidis, ${ }^{5}$ Athanassios Michos, ${ }^{1}$ Antigoni Siamopoulou-Mavridou, ${ }^{3}$ Maria Kalmanti, ${ }^{4}$ Heleni Papadopoulou, ${ }^{5}$ Emmanuel Roilides, ${ }^{5}$ Maria Theodoridou, ${ }^{1}$ George A Syrogiannopoulos, ${ }^{2}$ Vassiliki Syriopoulou, ${ }^{1}$ Greek Rotascore Extension Study Group

${ }^{1}$ First Department of Pediatrics, Athens University, Aghia Sophia Children's Hospital, ${ }^{2}$ Pediatric Department, University Hospital of Larissa, Larissa, Greece, ${ }^{3}$ Department of Pediatrics, University Hospital of Ioannina, Ioannina, Greece, ${ }^{4}$ Department of Pediatrics, University Hospital of Heraklion, Heraklion, Greece, ${ }^{5}$ First and Third Department of Pediatrics, Aristotle University, Ippokration Hospital of Thessaloniki, Thessaloniki, Greece

Pharmaceutical companies VIANEX, Athens-Greece and Sanofi Pasteur MSD, LyonFrance provided the test kits of rotavirus antigen stool detection.

Disclaimer: Georgios Trimis has to declare that he is Consultant in the pharmaceutical company VIANEX Athens-Greece, representative of Sanofi Pasteur MSD Lyon-France in Greece, which has the marketing authorization of RotaTeq (rotavirus vaccine) in Greece. All the other authors have not any financial relationship to disclosure.

Address of correspondence: Vassiliki Syriopoulou, M.D.

First Department of Pediatrics, First Department of Pediatrics, Athens University, Aghia Sophia Children's Hospital, Thivon and Levadias Street, Athens, 11527, GREECE. Tel: +30 1074674 78, Fax: +30 2107467669 email: vsyriop@ med.uoa.gr Running head: Rotavirus gastroenteritis in Greece 
Rotavirus is the leading cause of acute gastroenteritis among young children worldwide. A prospective multi-center study was conducted (2007-2008) in 5 Pediatric Hospitals to determine the prevalence, the clinical characteristics, and genotype distribution of rotavirus infection in Greece. Faecal samples were examined for the presence of group A rotavirus antigen by immunochromatography. Rotavirus strains were subjected to $\mathrm{G}$ and $\mathrm{P}$ genotyping by reverse-transcriptase polymerase chain reaction (PCR) and sequencing. A total of 393 children (216 boys) of median age 23 months, participated in the study. Rotavirus was the cause of acute gastroenteritis in 166 children, $42.3 \%$ (CI 95\%, 37.4-47.1\%) of non-hospitalized and 47.8\% (CI 95\%, 41.7-53.9\%) of hospitalized patients. Rotavirus gastroenteritis occurred between December and April in $78.6 \%$ of the cases. Most children with RVG (77.8\%) were between 3 months and 3 years old. The mean value of Clark severity score was $12.9 \pm 5.1$ for RVG and $10.5 \pm 4.9$ for non-RVG $(\mathrm{p}<0.01)$. Genotypes were determined in 117 strains and their distribution was as following: G1P[8], 49\%; G2P[4], 31\%; G4P[8], 10\%; G9P[8], 9\%; and G8P[14], 1\%. Conclusion. Rotavirus is a frequent cause of acute gastroenteritis in Greece. The genotypes circulating are similar with those of other European countries.

KEY WORDS: epidemiological study; acute gastroenteritis; rotavirus; genotypes 


\section{INTRODUCTION}

Rotavirus Gastroenteritis is the leading cause of acute gastroenteritis in children aged $\leq 5$ years worldwide. Although the prevalence of the disease is similar in most geographic regions, the mortality is greater in developing countries due to malnutrition and poorer access to medical treatment [Butz et al., 1993; Cook et al., 1990; Giaquinto et al., 2007; Kavaliotis et al., 2007; Leung et al., 2005; Parashar et al., 2003; Raebel, Ou, 1999; Soriano-Gabarró et al., 2006; Van Damme et al., 2007a]. Rotaviruses are classified into $\mathrm{G}$ and $\mathrm{P}$ genotypes on the basis of the sequence diversities of the two outer layer proteins VP7 and VP4 respectively which are the two viral proteins that elicit neutralizing antibody responses [Parashar et al., 2003; Raebel, Ou, 1999]. Although genotypes G1P[8], G2P[4], G3[P8], G4 [P8] and G9[P8] are the predominant genotypes of the human strains circulating in most European countries, genotype variations have been observed among different geographic areas [Iturriza-Gómara et al., 2009]. The aim of the present study was to examine the epidemiology of rotavirus infection, the clinical characteristics and the genotype distribution in Greek children younger than 5 years of age.

\section{MATERIAL AND METHODS}

The present study was conducted in five Paediatric Hospitals located in different geographic areas of Greece (Athens, Thessaloniki, Larissa, Ioannina and Heraklion) between January 2007 and June 2008. These Hospitals cover nearly 65\% of Greek pediatric population (Athens Hospital alone covers the 40\%); however vast majority of mild to moderate and many severe cases of acute gastroenteritis are treated from primary care Pediatricians. Consecutive children aged $\leq 5$ years who presented to the emergency room with symptoms of acute gastroenteritis were evaluated. Disease 
severity was assessed by 24-point severity scale (Clark's scale), based on a clinical scoring system concerning the presence, intensity and duration of fever, vomiting, diarrhea, and changes in behaviour due to dehydration [Rosenfeldt et al., 2005]. Stool examination was performed in children after parents gave a written informed consent to participate in the study. No parents refused. Ethics Committee provided its approval prior to study initiation.

A rapid stool immunochromatographic test for rotavirus antigen detection (test VIKIA, BioMérieux) was used. Fecal samples tested within 24 hours and those positive for Rotavirus Group A antigen were stored at $4^{\circ} \mathrm{C}$. Viral RNA was extracted from $10 \%$ faecal suspensions in balanced salt solution with the guanidinium isothiocyanate/silica method [Boom et al., 1990]. Complementary DNA was synthesized from the extracted viral RNA using reverse transcriptase enzyme in the presence of random hexamers [Iturriza-Gómara et al., 1999] and was further characterised by semi-nested multiplex polymerase chain reaction (PCR) using specific primers for the VP7 and VP4 genes to identify the G and P types respectively [Gentsch et al., 1992; Gouvea et al., 1990; Iturriza-Gómara et al., 2000a; IturrizaGómara et al., 2004; Simmonds et al., 2008]. Amplification products were analysed by electrophoresis using a $2 \%$ agarose gel stained with ethidium bromide in TBE buffer. Specific segment sizes were visualised under ultraviolet light, and rotavirus genotypes were determined. For the strains which were not $\mathrm{P}$ typable by second round multiplex PCR, the first round PCR products were sequenced using the VP4 primers. Sequencing was also carried out for PCR products of VP7 gene in one strain that displayed the G12 type. Sequencing was performed in a collaborating laboratory (Biogenomica, Athens, Greece) and the results were analyzed with the Bioedit 
software package and aligned with the BLAST nucleotide search [http://blast.ncbi.nlm.nih.gov/Blast.cgi, 2010].

\section{RESULTS}

A total of 393 children of median age 23 months (range 2 months-5 years) participated in the study; 139 from Athens, 75 from Larissa, 71 from Ioannina, 57 from Heraklion, and 51 from Thessaloniki. Boys outnumbered girls by a ratio of 1.2 $(216 / 180)$. The proportion of rotavirus gastroenteritis per geographic region is presented in Fig. 1. Rotavirus was the cause of acute gastroenteritis in 166 children, 42.3\% (CI 95\%, 37.4-47.1\%) of non-hospitalized and 47.8\% (CI 95\%, 41.7-53.9\%) of hospitalized patients. The $78.6 \%$ of rotavirus gastroenteritis occurred in winter months, between December and April. Most children with rotavirus gastroenteritis (77.8\%) were between 3 months and 3 years old. The median age of rotavirus gastroenteritis diagnosis was 22 months (mean $20 \pm 12$ months), while the median age of non-rotavirus acute gastroenteritis was 25 months (mean $22 \pm 11$ months).

Behavioral changes (irritability, hypotonia), signs of dehydration, weight loss, fever $\geq 38^{0} \mathrm{C}$, vomiting, duration of diarrhea were more prevalent in rotavirus gastroenteritis than in non rotavirus gastroenteritis $(\mathrm{p}<0.01)$. Most children suffered from moderate (91.7\% for rotavirus gastroenteritis vs $92.4 \%$ for non rotavirus acute gastroenteritis) or severe $(7.1 \%$ for rotavirus gastroenteritis vs $6.1 \%$ for non rotavirus acute gastroenteritis) gastroenteritis (9-16 points and 17-24 points respectively). The mean value of severity was $12.9 \pm 5.1$ for rotavirus gastroenteritis and $10.5 \pm 4.9$ for non rotavirus acute gastroenteritis $(\mathrm{p}<0.01)$.

Children with rotavirus gastroenteritis as compared to those with non-rotavirus acute gastroenteritis were more likely to need clinical reevaluation during the course 
of the disease ( 85.5 vs $74.9 \%, \mathrm{p}<0.05)$, get hospitalized $(72.9 \%$ vs $60.8 \%, \mathrm{p}<0.05)$, have greater hospitalization time (median 4 vs 3 days, mean $4.2 \pm 2.7$ vs $4 \pm 2.4$ days) and more parents' days of absence from work (median 4 vs 3 days, mean $4.5 \pm 2.9$ vs $3.8 \pm 2.6$ days, $\mathrm{p}<0.05)$. No patient with rotavirus gastroenteritis had received any rotavirus vaccine.

One hundred seventeen of the 166 rotavirus gastroenteritis positive samples (70\%) were available for genotyping. The other 49 rotavirus gastroenteritis positive samples were not properly stored or the quantity was not adequate. All of the analyzed strains were successfully G typed by PCR. Sequence analysis of the VP4 gene was carried out for 15 strains that could not be $\mathbf{P}$ typed by PCR. Fourteen of those strains were classified as $\mathrm{P}[8]$ and one strain as $\mathrm{P}[14]$. The last strain that displayed the unusual G12P[14] type was further analyzed by sequencing the VP7 and VP6 gene and was finally identified as G8P[14] group A rotavirus subgroup I. Two mutations were detected at nt 1 and 8 from the primes's 3' end of VP4 gene (C:A and T:G, respectively). Alignment of the VP7 sequencing demonstrated 3 base-pair mismatches at the positions nt 1,10 and 15 from the primers' 3' end, which prevented G8 specific primer binding to the G8 primer binding site, whereas the great homology of the G12 primer with the corresponding binding site of the VP7 sequence resulted to the G12 mistype.

One hundred sixteen of the $117(99 \%)$ strains belonged to the most common genotypes that circulate in Europe during the last years [10,20], while 1 strain (1\%) belonged to an uncommon genotype, G8P[14]. The distribution of the genotypes across the country (G1P[8] 49\%, G2P[4] 31\%, G4P[8] 10\%, G9P[8] 9\% and G8P[14] $1 \%$ ) and differences in genotype distribution by geographic region are shown in Fig. 2 
(A and B). No association was observed between genotypes and patients' age, severity of disease, and hospitalization rate.

\section{DISCUSSION}

The clinical burden of rotavirus gastroenteritis in Greece has a similar profile with that observed in other European countries. Rotavirus is the most common cause of acute gastroenteritis in children up to 5 years old in Greece (main risk period between 3 months and 3 years old), it has a greater clinical burden compared to non rotavirus acute gastroenteritis, and it occurs more frequently in winter months [Parashar et al., 2003; Soriano-Gabarró et al., 2006; Van Damme et al., 2007a]. Rotavirus gastroenteritis is responsible for nearly half of the cases visiting emergency clinics or requiring hospitalization due to acute gastroenteritis in Greek children up to 5 years of age $(42.3 \%$ and $47.8 \%$ respectively); prevalence that is close to that reported in other studies conducted worldwide and in a previous study held in Greece (Kavaliotis et al., 2007; Soriano-Gabarró et al., 2006). However, Levidiotou et al, reported a lower prevalence $(\mathbf{2 1 . 3 5 \% )}$ ) of rotavirus infection in hospitalized children in Northwest Greece (Levidiotou et al., 2009). The different results obtained by the latter group may reflect differences in the screened population (different years and geographic regions) as well as in the detection method.

Factors such as hospitalizations, emergency visits, increased mean hospitalization time (4.2 days), lost working days from parents (4.5 days as a mean) indicate social and economic cost, except from increased burden of Health System and suffering of children and their families. A limitation of the present study is that nosocomial infections, where rotavirus is the leading cause of acute gastroenteritis [Parashar et al., 2003], cases visiting pediatric offices in community and domiciliary episodes are not included. 
In this report, the preliminary results of the first multicenter Hellenic study to determine the rotavirus genotypes circulating in Greece are presented. The predominant genotype was the G1P[8] which is the commonest worldwide, followed by G2P[4], G4P[8], G9P[8] that represent $99 \%$ of the circulating genotypes in this geographic region and are together with the G3P[8] the 5 commonest in Europe and worldwide [Iturriza-Gómara et al., 2009; Van Damme et al., 2007b]. Similarly with other countries [Iturriza-Gómara et al., 2009], some genotype variation was observed across the country; G2P[4] was the predominant genotype in southern and northern Greece (Thessaloniki, Heraklion) and G1P[8] in central Greece (Athens, Larissa).

\section{Mismatches between the $P[8]$ specific primer and its complementary region of} the VP4 cDNA in the P[8] isolates would explain the failure of the typing RTPCR of 15 strains. Of note, one strain was identified as P[14] and was closely related to human Rotavirus A P[14] strains isolated in Italy (PR/1300/04) and Hungary (Hun5) (maximum identity at nucleotide level 97\% and 96\% respectively) [Medici et al., 2008]. The VP7 gene of the same strain was identified as G8 and displayed high similarity to the Egyptian human Rotavirus A strain EGY1850 (maximum identity at nucleotide level 96\%), while the sequence analysis of the VP6 gene identified it as subgroup I and displayed high nucleotide identity (97\%) to the Slovenian Human Rotavirus A strain SI-R241/07 [Holmes et al., 1999]. This uncommon strain G8P[14] was detected from a non-hospitalized child living in a rural region of Larisa who may have close contact with animals, and is possibly the result of reassortment between human and animal strains during coinfection [Holmes et al., 1999; Medici et al., 2008; Santos, Hoshino, 2005]. There are few reports that associate P[14] with G types in humans, because $\mathrm{P}[14]$ is a rotavirus type that has been detected mostly in animals [Holmes et al., 1999; Matthijnssens et al., 2009; Medici et al., 2008; Santos, 
Hoshino, 2005]. G8 is a rotavirus type that can be found in cows at relatively high frequency and presents a great diversity of G-P combinations [Santos, Hoshino, 2005] In the previous decades human G8 was circulating mostly in tropical regions like Indonesia, Brazil and Africa and sporadically in some European countries like Finland, Italy and United Kingdom [Holmes et al. 1992]. Recently has reported mistyping of G8 human strains as G12 due to point mutations at the G8 specific primer binding site and the G8 and G12 primers were necessarily redesigned [Aladin et al., 2010]. Interspecies transmission events and genome reassortment are frequently reported in the evolution history of rotavirus and highlight the role of animals as a source of rotavirus infection in humans [Matthijnssens et al., 2008a]. Sequencing of its genome and adopting a new classification system are recommended to generate reliable data and elucidate the rotavirus evolutionary patterns [Matthijnssens et al., 2008b].

Rotavirus strains circulating in Greece are well covered by current vaccines. However, as there is seasonal fluctuation, next years results will help to form a more representative picture for rotavirus genotypes prevalence in Greece. Surveillance studies are necessary to monitor the changes in strain distribution during the pre- and post-vaccine era and to detect the emergence of antibody escape mutants that may occur after implementation of rotavirus vaccines [Iturriza-Gómara et al., 2009; Iturriza-Gómara et al., 2000b]. Although there is a limitation from the small sample size, results confirm that there is not a constant different distribution of rotavirus genotypes in non hospitalized compared to hospitalized patients with rotavirus gastroenteritis, either a different distribution in age groups, except neonates (not any case from this group in this study) [Parashar et al., 2003]. 
Rotavirus vaccination has diminished rotavirus activity in other countries; while, especially in USA, herd immunity has been demonstrated [CDC, 2008]. Medical societies, as ESPID and ESPGHAN, recommend introduction of routine infant rotavirus vaccination in European countries as a cost effective means of rotavirus gastroenteritis impact on society [Vesikari et al., 2008].

Rotavirus gastroenteritis has a major clinical burden in children between 3 months and 3 years old, a period where rotavirus vaccines have proven their efficacy against disease related to the serotypes that seem prevalent in Greece. This study supports the need for implementation of routine rotavirus vaccination program in Greece in order to reduce rotavirus gastroenteritis clinical burden and the associated cost for health care system. 


\section{ACKNOWLEDGEMENTS}

We would like to thank all the members of the Greek Rotascore Extension Study Group, for their important contribution to the implementation of the epidemiological study.

We would like also to thank pharmaceutical companies VIANEX, Athens-Greece and Sanofi Pasteur MSD, Lyon-France for providing the test kits of rotavirus antigen stool detection. 


\section{REFERENCES}

Aladin F, Nawaz S, Iturriza-Gomara M, Gray J. 2010. Identification of G8 rotavirus strains determined as G12 by rotavirus genotyping PCR: updating the current genotyping methods. J Clin Virol 47:340-4.

Boom R, Sol C, Salismans M, Jansen C, Wertheim-van Dillen P, Van den Noordaa J. 1990. Rapid and simple method for the purification of nucleic acids. J Clin Microbiol 28: 495-503.

Butz AM, Fosarelli P, Dick J, Cusack T, Yolken R. 1993. Prevalence of rotavirus on high-risk fomites in day-care facilities. Pediatrics 92:202-5.

CDC. 2008. Early Release. Delayed Onset and Diminished Magnitude of Rotavirus Activity - United States, November 2007 - May 2008. (June 25, 2008). MMRW $57: 1-4$

Cook SM, Glass RI, LeBaron CW, Ho MS. 1990. Global seasonality of rotavirus infections. Bull World Health Organ 68:171-7.

Gentsch J, Glass R, Woods P, Gouvea V, Gorziglia M, Flores J, Das, B, Bhan M. 1992. Identification of group A rotavirus gene 4 types by polymerase chain reaction. $\mathbf{J}$ Clin Microbiol 30:1365-73. 
Giaquinto C, Van Damme P, Huet F, Gothefors L, Maxwell M, Todd P, Da Dalt L; REVEAL Study Group. 2007. Clinical Consequences of Rotavirus Acute Gastroenteritis in Europe, 2004-2005: The REVEAL Study. J Infect Dis 195:S26-S35.

Gouvea V, Glass R, Woods P, Taniguchi K, Clark H, Forrester B, Fang Z. 1990. Polymerase chain reaction amplification and typing of rotavirus nucleic acid from stool specimens. J Clin Microbiol 28:276-282.

Holmes JL, Kirkwood CD, Gerna G, Clemens JD, Rao MR, Naficy AB, AbuElyazeed R, Savarino SJ, Glass RI, Gentsch JR. 1999. Characterization of unusual G8 rotavirus strains isolated from Egyptian children. Arch Virol 144:1381-96.

http://blast.ncbi.nlm.nih.gov/Blast.cgi; last updated 30-3-10.

Iturriza-Gómara M, Green J, Brown D, Desselberger U, Gray J. 1999. Comparison of specific and random priming in the reverse transcriptase polymerase chain reaction for genotyping group A rotaviruses. J Virol Methods 78: 93-103.

Iturriza-Gómara M, Green J, Brown D, Desselberger U, Gray J. 2000a. Diversity within the VP4 gene of rotavirus P[8] strains: Implications for RT-PCR genotyping. J Clin Microbiol 38:899-901.

Iturriza-Gómara M, Green J, Gray J. 2000b. Methods of rotavirus detection, sero-and genotyping, sequencing and phylogenetic analysis. (Chapter 10; pp189-217) in 
Rotaviruses: Methods and Protocols. Methods in Molecular Medicine, Edited by J.J. Gray and U. Desselberger. Humana Press, Totowa, NJ, USA.

Iturriza-Gómara M, Kang G, Gray J. 2004. Rotavirus Genotyping: Keeping up with an evolving population of human rotaviruses. J Clin Virol. 31:259-265.

Iturriza-Gómara M, Dallman T, Bányai K, Böttiger B, Buesa J, Diedrich S, Fiore L, Johansen K, Korsun N, Kroneman A, Lappalainen M, László B, Maunula L, Matthinjnssens J, Midgley S, Mladenova Z, Poljsak-Prijateli M, Pothier P, Ruggeri F, Sanchez-Fauquier A, Schreier E, Steyer A, Sidaraviciute I, Tran A, Usonis V, Van Ranst M, De Rougemont A, Gray J. 2009. Rotavirus surveillance in Europe, 20052008: web-enabled reporting and real-time analysis of genotyping and epidemiological data. J Infect Dis 200,Suppl 1:S215-21.

Kavaliotis I, Papaevangelou V, Aggelakou V, Mantagou L, Trimis G, Papadopoulou V, Vlachaki G, Nikolakopoulou N, Konstantopoulos A; Greek ROTASCORE Study Group. 2008. ROTASCORE Study: Epidemiological observational study of acute gastroenteritis with or without rotavirus in Greek children younger than 5 years old. Eur J Pediatr 167:707-8.

Leung AK, Kellner JD, Davies HD. 2005. Rotavirus gastroenteritis. Adv Ther 22:476-87. 
Levidiotou S, Gartzonika C, Papaventsis D, Christaki C, Priavali E, Zotos N, Kapsali

E, Vrioni G. 2009. Viral agents of acute gastroenteritis in hospitalized children in Greece. Clin Microbiol Infect 15:596-8.

Matthijnssens J, Ciarlet M, Heiman E, Arijs I, Delbeke T, McDonald SM, Palombo EA, Iturriza-Gómara M, Maes P, Patton JT, Rahman M, Van Ranst M. 2008a. Full genome-based classification of rotaviruses reveals a common origin between human Wa-Like and porcine rotavirus strains and human DS-1-like and bovine rotavirus strains. J Virol 82:3204-19.

Matthijnssens J, Ciarlet M, Rahman M, Attoui H, Banyai K, Estes MK, Gentsch JR, Iturriza-Gómara M, Kirkwood CD, Martella V, Mertens PP, Nakagomi O, Patton JT, Ruggeri FM, Saif LJ, Santos N, Steyer A, Taniguchi K, Desselberger U, Van Ranst M. 2008b. Recommendations for the classification of group A rotaviruses using all 11 genomic RNA segments. Arch Virol 2008 153:1621-9.

Matthijnssens J, Potgieter CA, Ciarlet M, Parreno V, Martella V, Banyai K, Garaicoechea L, Palombo EA, Novo L, Zeller M, Arista S, Gerna G, Rahman M, Van Ranst M. 2009. Are human $\mathrm{P}[14]$ rotavirus strains the result of interspecies transmissions from sheep or other ungulates that belong to the mammalian order Artiodactyla? J Virol 83:2917-29.

Medici MC, Abelli LA, Martinelli M, Dettori G, Chezzi C. 2008. Molecular characterization of VP4, VP6 and VP7 genes of a rare G8P[14] rotavirus strain detected in an infant with gastroenteritis in Italy. Virus Res 137:163-7. 
Parashar UD, Hummelman EG, Bresee JS, Miller MA, Glass RI. 2003. Global illness and deaths caused by rotavirus disease in children. Emerg Infect Dis 9:565-72.

Raebel MA, Ou BS. 1999. Rotavirus disease and its prevention in infants and children. Pharmacotherapy 19:1279-95.

Rosenfeldt V, Vesikari T, Pang XL, Zeng SQ, Tvede M, Paerregaard A. 2005. Viral etiology and incidence of acute gastroenteritis in young children attending day-care centers. Pediatr Infect Dis J 24:962-5.

Santos N, Hoshino Y. 2005. Global distribution of rotavirus serotypes/genotypes and its implication for the development and implementation of an effective rotavirus vaccine. Rev Med Virol 15:29-56.

Simmonds M, Armah G, Asmah R, Banerjee I, Damanka S, Esona M, Gentsch J, Gray J, Kirkwood C, Page N, Iturriza-Gómara M. 2008. New oligonucleotide primers for P-typing of rotavirus strains: Strategies for typing previously untypeable strains. Journal of Clinical Virology 42:368-73.

Soriano-Gabarró M, Mrukowicz J, Vesikari T, Verstraeten T. 2006. Burden of rotavirus disease in European Union countries. Pediatr Infect Dis J 25:S7-S11.

Van Damme P, Giaquinto C, Huet F, Gothefors L, Maxwell M, Van der Wielen M; REVEAL Study Group. 2007a. Multicenter Prospective Study of the Burden of 
Rotavirus Acute Gastroenteritis in Europe, 2004-2005: The REVEAL Study. J Infect Dis 195:S4-S16.

Van Damme P, Giaquinto C, Maxwell M, Todd P, Van der Wielen M; REVEAL Study Group. 2007b. Distribution of rotavirus genotypes in Europe, 2004-2005: the REVEAL Study. J Infect Dis 195, Suppl 1:S17-25.

Vesikari T, Van Damme P, Giaquinto C, Gray J, Mrukowicz J, Dagan R, Guarino A, Szajewska H, Usonis V; Expert Working Group; European Society for Paediatric Infectious Diseases; European Society for Paediatric Gastroenterology, Hepatology, and Nutrition. 2008. European Society for Paediatric Gastroenterology, Hepatology and Nutrition/ European Society for Paediatric Infectious Diseases Evidence - based Recommendations for Rotavirus Vaccination in Europe. JPGN 46, Suppl 2:S38-S48. 
FIG. 1. Proportion (\%) of RVG per Hospital ( $N=393)$.

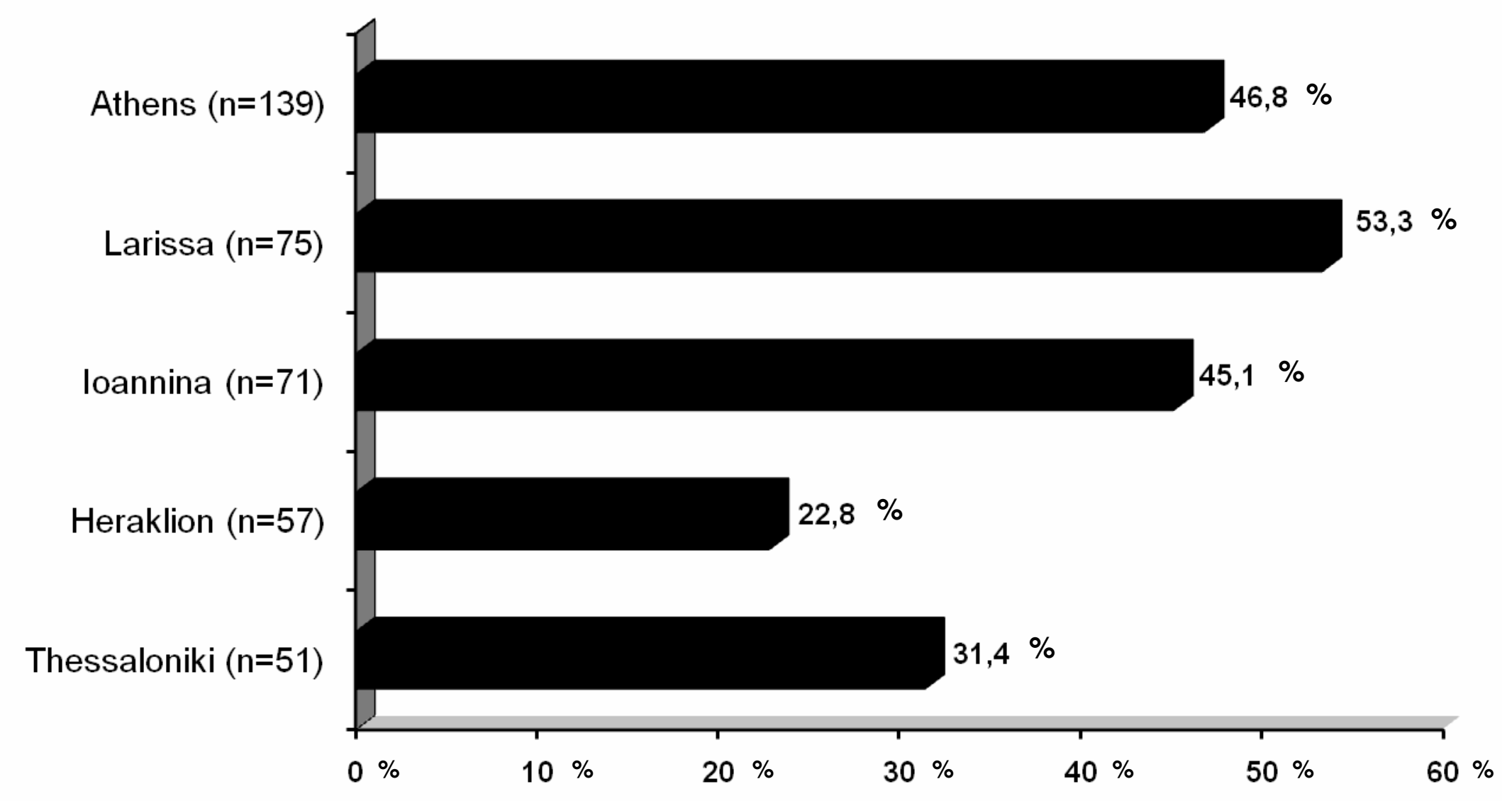


Fig. 2. Distribution of Rotavirus Group A genotypes (\%) in Greece during 2007-2008 $(\mathrm{N}=117)$

A

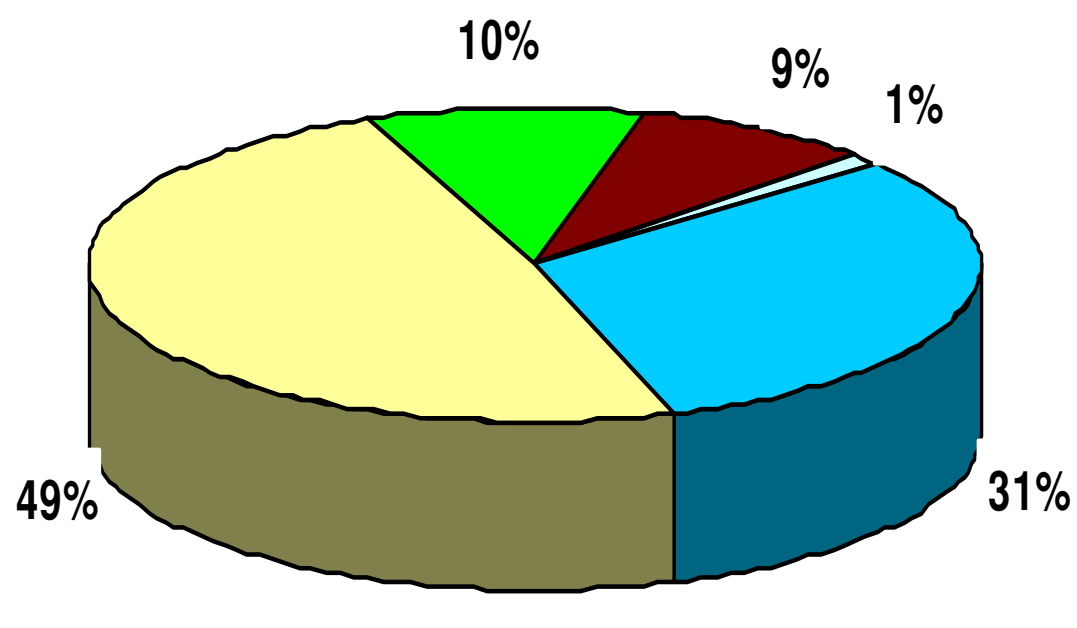

$\mathrm{N}=117$
B

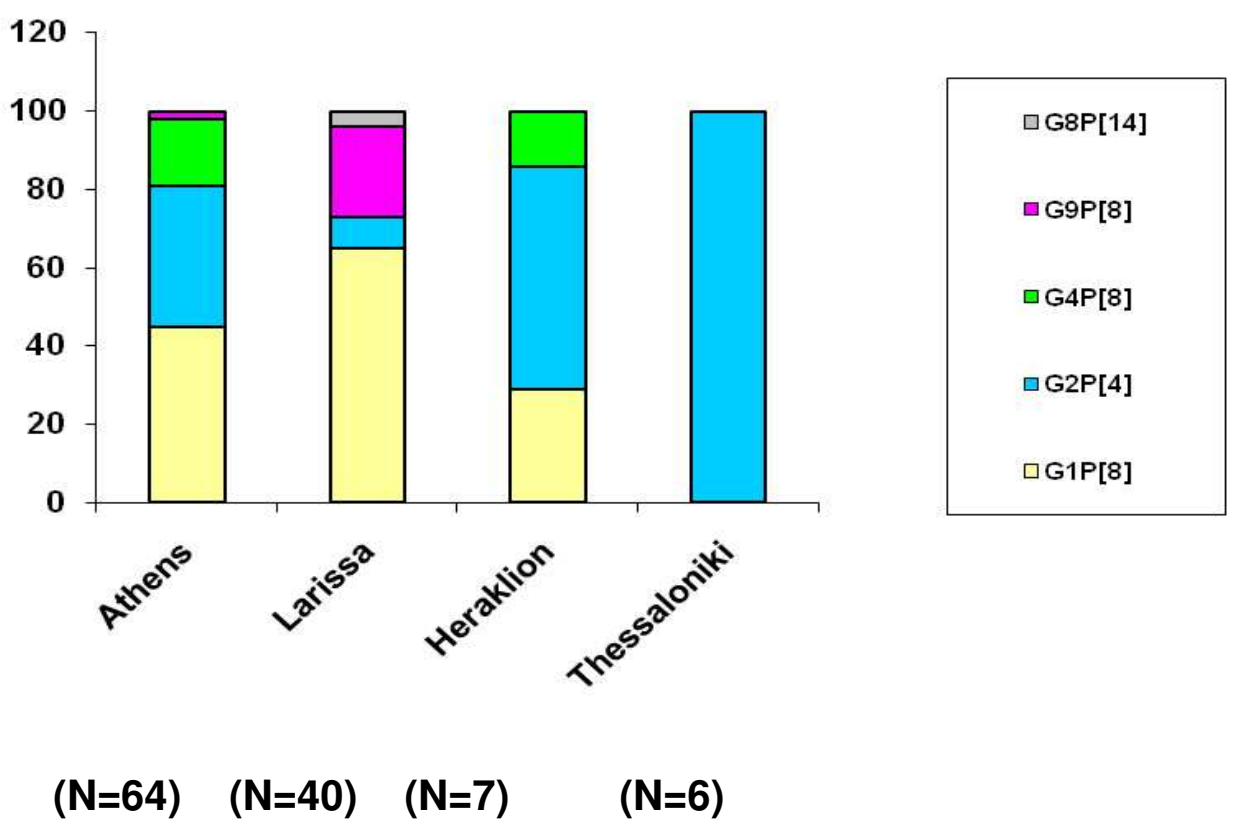

